\title{
Envisioning the Dutch Imperial Nation-State in the Age of Revolutions
}

\author{
René Koekkoek
}

The late eighteenth-century transformation of the Dutch company-ruled trading empire into a state-ruled colonial empire was a turning point in the history of visions of the Dutch empire. ${ }^{l}$ It coincided, although this is rarely emphasized, with the Dutch Republic's transformation of a union of seven 'United Provinces' into a centralized nation-state. In the second half of the 1790s, Dutch 'Batavian' revolutionaries abandoned the model of fragmented, decentralized sovereignty that had characterized early modern Dutch politics. Instead, they realized a new conception of political sovereignty, known in contemporary revolutionary parlance as 'one and indivisible' (één en ondeelbaar). This formal, constitutional foundation of a centralized Dutch state ruled by one supreme authority was complemented with a new model of imperial sovereignty. During the Batavian Revolution (1795-1801), the company-owned overseas territories and properties were redefined as 'possessions of the state' over which the state had political sovereignty. The Batavian Revolution laid the conceptual foundations of national and colonial state-building. ${ }^{2}$

R. Koekkoek ( $\square)$

Department of History and Art History, Utrecht University, Utrecht, The Netherlands e-mail: r.koekkoek@uu.nl

(C) The Author(s) 2019

R. Koekkoek et al. (eds.), The Dutch Empire between Ideas and Practice, 1600-2000, Cambridge Imperial and Post-Colonial Studies Series, https://doi.org/10.1007/978-3-030-27516-7_7 
But what were these conceptual foundations? In what circumstances were they formulated? Historians of the nineteenth-century Dutch colonial empire have largely ignored the political ideas of the 1790s and early 1800 s, save the obligatory reference to the clash between the 'liberal' critic of Dutch colonial policy, Dirk van Hogendorp, and the 'conservative' representative of the colonial establishment, S.C. Nederburgh. It is telling that the two most important studies on Dutch imperial political thought in the age of Atlantic revolutions date from the 1940s and 1970s. ${ }^{3}$ Subsequent generations of historians have shrugged off the actual content of ideas and debates concerning the empire during the revolutionary era. The tenor has been that Batavian revolutionaries 'achieved little', their ideas being dismissed as a 'potpourri of progressive and conservative ideas'. ${ }^{4}$ In such renderings, the colonies simply 'fell to' the state. ${ }^{5}$ The realization of a new conception of imperial sovereignty vested in a centralized state has been assumed rather than explored.

This disregard for the political-theoretical underpinnings of the transformation of imperial sovereignty has been accompanied by somewhat one-dimensional postulations of the rise of abstract Enlightenment ideals concerning free trade, abolitionism, and 'benevolent' colonial rule. How to account for that fact that Batavian revolutionaries did not abolish slavery, did not open up free trade in every sector and area, and did not implement colonial policies based on the equal rights of man? It has been widely asserted that their Enlightenment ideals were either 'inconsequential' or 'wishy-washy', that revolutionaries 'failed to live up to their ideals', or that, in the end, economic motives prevailed. Such evaluations, however, reek of anachronism and will help us little in understanding the relationship between ideas and this foundational constitutional moment. ${ }^{6}$

This chapter revisits the era of the Batavian Revolution as a keymoment in the history of Dutch imperial political thought. It argues that in terms of formal political organization, the conceptual and intellectual foundations of the nineteenth-century Dutch imperial state were laid during the Batavian Revolution. A crucial context for this foundational moment, I maintain, is the age of Atlantic, 'imperial' revolutions. Considering the various alternatives that were on the table, the dead ends, and the roads not taken, this chapter presents the years surrounding 1800 not as a moment when Dutch imperial history was 'on hold', but as a turning point that gave birth to a state-led colonial empire.

My contribution thereby proceeds from the intersection of three historiographical trends. First, over the past two decades the 'Age of 
Atlantic Revolutions' has been studied not merely as an age of 'democratic' and 'national' revolutions, but increasingly as an age of 'imperial' revolutions. Atlantic revolutions did not necessarily or automatically lead to neatly defined nation-states. ${ }^{7}$ This observation applies to the Dutch Batavian Revolution too. The imperial dimensions of both the American and French revolutions were in this regard particularly instructive for Batavian revolutionaries. To them the British and French imperial policies represented failures, albeit of different sorts and leading to different outcomes. Putting these contexts centre stage enables us to better grasp the considerations and anxieties surrounding the formulation of new visions of the Dutch empire. ${ }^{8}$

A second, closely related topic that has received growing scholarly attention in recent decades is the major slave insurrection on the French-Caribbean island of Saint-Domingue that led to the first independent black American state Haiti, including its repercussions in the wider Atlantic world. To be sure, Batavian revolutionaries did not see a 'Haitian Revolution'; they saw a French revolutionary regime struggling with a slave rebellion in the world's most profitable plantation colony. Both within and outside the Batavian National Assembly references to this series of events, in particular to Frenchmen 'prematurely' applying the principle of the equal rights of man to enslaved people of African descent, were ubiquitous. Such interpretations reveal a deeply held conviction among even the most radical Batavian revolutionaries that enslaved Africans were (still) 'unfit' for the liberties and rights associated with citizenship due to their alleged backward stage of civilization. ${ }^{9}$ Such modes of reasoning came to be applied to the indigenous inhabitants of the East Indies too. ${ }^{10}$

Finally, in contrast to an older-and in my view mistaken-historiography that has painted the Dutch Batavian revolutionaries as 'puppets' of the French revolutionary republic, a spate of recent research on the Batavian Republic has demonstrated that Dutch revolutionaries could operate and debate in relative autonomy. During the period 1795-1798 a rich, and vibrant political debate took place among Batavian revolutionaries about what it means - and what it requires - to be(come) a modern, representative democratic republic within the framework of a centralized state. ${ }^{11}$ Although the democratic-republican ideals proved to be shortlived, the framework of the centralized nation-state became permanent. Taking into account the Batavian redefinition of the Dutch empire, 
however, points to an additional legacy: the framework of an imperial nation-state'. ${ }^{12}$

Bringing these historiographical trends into dialogue with each other, this chapter sheds a new light on an underexplored key-moment in the history of visions of the Dutch empire. How was the Dutch empire envisioned during the era of the Batavian Revolution? What options were on the table? And what was the legacy of this revolutionary moment?

In what follows I will first sketch the precarious state of the Dutch empire in the closing decade of the eighteenth century. I then turn to the 'Committee concerning the East Indian Trade and Possessions' established in 1795 under the leadership of the democratic-republican revolutionary Samuel Wiselius. Despite this Committee's cautious formulation of a constitutionally unified imperial realm, there was never an unqualified intention to apply the revolutionary principle of the equal rights of man to all-Dutch and non-Dutch-inhabitants of the imperial realm. The chapter goes on to discuss the next prominent Committee on colonial affairs established by the Batavian National Assembly in early 1797. Chaired by representative Jacob Hendrik Floh, this Committee produced a fundamental restatement of the nature of Dutch empire: the colonies were subordinate 'possessions' of the state bereft of the right of representation in the legislative body; they principally served to enhance the wealth and glory of the Dutch state; and they were to be ruled by state (civil) servants, not by company-employed merchants; the non-Dutch inhabitants of the colonies-enslaved or subjected by other (violent) means-were, notwithstanding some critical voices, generally seen as uncivilized and unfit to be entitled to the rights and liberties assigned to Dutch citizens. This model constituted not a 'failure' of 'inconsequential' ideals, but a conscious expression of a vision of empire that would have a lasting impact on nineteenth-century colonial state-building.

This chapter accordingly shows how ideas and visions were translated into imperial political frameworks. The imperial visions of these committees were subject to parliamentary deliberation and informed new constitutional settlements. They can be seen as bridging the realm of imperial ideas and the realm of imperial practices. At the same time, the larger context of Atlantic imperial revolutions and practices, warfare and insecurity, deeply affected the ways in which Dutch revolutionaries reimagined their empire. 


\section{A Fragile Empire}

The Dutch empire is in a 'critical political situation', national representative Herman Vitringa remarked in April 1797. His assessment was illustrative for the pessimistic mood among his colleagues who were plagued by a 'fatal insecurity about what we have left or will have left of it'. ${ }^{13}$ Indeed, at the closing of the eighteenth century, the geopolitical prospects for new imperial blueprints grounded in revolutionary principles were grim. During the second half of the 1790s the fate of the entire Dutch empire trembled in the balance. After the invasion of the FrenchBatavian army in January 1795, the stadtholder William V of Orange and his retinue fled to England. From Kew Palace, London, his place of exile, Willem $\mathrm{V}$ in his former capacities as captain-general of the Dutch army and director-general of the VOC ordered colonial authorities to temporarily take refuge under the protective wings of British forces against French intrusions. Dutch Guyana (Berbice, Demerara, Essequibo), Cape the Good Hope, and nearly all Indian and East Indian enclaves and settlements came under British rule. The island of Java, the VOC's colonial stronghold in the East, as well as Suriname and the six tiny islands of both the Antilles remained in Batavian hands. ${ }^{14}$ The West-Indian (Antillean) possessions were only transferred to the British and the French in 1799-1800. Trade and communication between the revolutionary Batavian Republic and the colonies, furthermore, had virtually come to a standstill due to the superiority of a hostile British navy. For Batavian revolutionaries it was a sobering geopolitical reality-check; they were nearly powerless in the face of their mighty rivals.

Yet we should not lose sight of the genuine hope, cherished by many Dutch revolutionaries at the time, that both the East and West Indies could be made profitable again. ${ }^{15}$ Notwithstanding the commonplace of Dutch economic decline in the second half of the eighteenth century, Dutch overseas trade in the Atlantic world was quite successful and even growing until at least the early 1780s. ${ }^{16}$ Over the course of the eighteenth century, the slave-based plantation economy in Dutch Guyana and Suriname had grown significantly; the islands of Curacao and St. Eustatius had become thriving commercial hubs. Although the Dutch imperial presence in the Atlantic world was characterized by its decentralized nature, its entanglement with other Atlantic empires, and its role as 'broker' rather than expansionist imperialist, Batavian revolutionaries 
envisioned the West-Indian possession as belonging to a Dutch imperial realm. ${ }^{17}$ In contrast to the East Indian possessions, the West Indian colonies were considered 'agricultural settler colonies' (landbouwende volksplantingen) whose (white Dutch) inhabitants were directly related to the motherland. The East Indian colonial possessions were rather referred to as 'Establishments' (Etablissementen) directed at the export of colonial products solely destined for the metropolitan market. Batavian revolutionaries were well aware that under the VOC profits had decreased, but in the preceding decades the overall volume of trade was still considerable. The question became how to reform this 'unprofitable giant'. ${ }^{18}$

The bottom line is that at the outbreak of the revolution in 1795, many believed that Dutch overseas trade was not necessarily doomed. In late 1797, the Wiselius Committee considered the East and West Indian Possessions 'the most powerful sinews of this State'. ${ }^{19}$ The question was how Dutch overseas trade could flourish again without chartered companies, and how the organization of the Dutch empire could be put on a new footing.

To appreciate the establishment of the Dutch state's sovereignty over the colonies, it is worthwhile considering what kind of regime of imperial sovereignty it replaced. Following Philip J. Stern's lead, several scholars of early modern Dutch imperial history have pointed out that just like the British East India Company (EIC) the Dutch United East India Company (VOC) and the Dutch West India Company (WIC) were never merely companies involved in trade. The VOC owned and administered territories; it constructed and manned fortifications, administered justice and imposed punishments through courts, drew up legislation, levied taxes, had a monopoly of violence (in certain areas), possessed and maintained military forces, regulated civic and religious life, entered into diplomatic alliances with foreign rulers, made treaties and declared war. These marks of sovereignty usually associated with states suggest that trading companies were institutions 'between company and state' or, in Stern's terms, 'company-states'. Instead of seeing early modern trading companies as either precursors of the modern multinational or as 'anomalies', that is to say, as 'strange' political-economical organizations that are hard to square with the nation-state, it has been convincingly argued that the hybrid nature of trading companies should be analysed on its own terms. ${ }^{20}$ Trading companies such as the EIC or VOC, were 'corporate body politics' in a period when the supreme authority of the state 
was not fully established. From this perspective, the political nature of trading companies was not abnormal. They belong to a multitude of corporate bodies (or corporations) that constituted early modern societies, such as guilds, cities, provincial estates, universities, domestic chambers of commerce and trade, ecclesiastical chapters and confraternities. Against this background, the state claiming supreme authority over colonies that were redefined as possessions of the state was part of a larger revolutionary effort to eradicate ancien régime forms of corporate sovereignty. ${ }^{21}$

\section{Finding a Middle Course}

The regime change following the invasion of French-Batavian armies in January 1795 was a fairly smooth affair; the major challenge was what kind of regime should replace the old one. The very foundations of a new political system were up for debate: the form of government, the structure of the state, and the nature of the sovereignty of the 'people'. For who was 'the people'? Was there a single Dutch 'nation' at all? This was no foregone conclusion given the age-old, traditional autonomy of the Dutch provinces. And what about the Dutch-and non-Dutchinhabitants of the colonies? Were they also part of the sovereign nation? It took more than a year for Dutch revolutionaries to arrive at a consensus that a 'national' meeting of representatives should convene to decide on these matters in the first place. ${ }^{22}$

On 1 March 1796, the prominent lawyer and author of the celebrated Treatise on Equality, Pieter Paulus, held his opening address as first chairman of the National Assembly in The Hague. Around the same time the revolutionary Batavian Republic was also entering uncharted imperial waters. On December 24, 1795, a few months before it would be replaced by the National Assembly as the country's highest political body, the States General had decreed the dissolution of the VOC. The (second) WIC was already liquidated in 1792, its territories and assets placed under direct rule of the States General. ${ }^{23}$ Although the VOC's colonial patent was prolonged to 1798 (and again postponed to 1799), the company's directors were deposed immediately, their tasks assumed by the newly formed 'Committee concerning the East Indian Trade and Possessions'. It was up to them to begin rethinking the political and constitutional status of the overseas 'possessions'. ${ }^{24}$ 
The Committee consisted of 21 members: fiery democratic-republican as well as more moderate revolutionaries; some with experience or roots in the East, others without; even some former VOC directors were joined in. ${ }^{25}$ The young and diligent Samuel Wiselius, who had risen to prominence as a principled Patriot publicist and who had played an active role in the regime change in both Amsterdam and the province of Holland, became the undisputed leader of the Committee. In December 1796, the Committee offered a first draft of articles to the Constitutional Reform Commission (chaired by Jacob Hahn) that was formed to review the first, heavily contested draft constitution (Plan van constitutie). This draft constitution was supposed to serve as a working document for the National Assembly's deliberations. ${ }^{26}$ The accompanying report to the draft articles on the colonies, written by Wiselius, stated that 'those countries hitherto entitled Possessions and Colonies from now on must be considered inseparable parts of the single and indivisible Republic'. This formulation reveals the Committee's intention to transpose the principle of éen-en ondeelbaarheid (unity and indivisibility), the political creed of those Batavian revolutionaries who desired a centralized nationstate, to the imperial realm. As a second basic principle the Committee's report proposed that 'everything that is just and fair here ought to be just and fair there, and consequently that everywhere throughout the Batavian Republic rights and duties are the same'. ${ }^{27}$

Although a detailed exposition of constitutional stipulations was still missing, this proposal amounted to a sweeping revision of the political architecture of the empire. Such ideas did not come out of nowhere. Already in 1785, the (anonymous) author of a notorious pamphlet series in the form of fictitious letters between 'Aristodemus' and 'Sincerus', a work influenced by the writings of the French Abbé Guillaume-Thomas Raynal, advocated the principles that, first, colonies are 'parts' of the motherland, and second, that citizens in the colonies ought to remain full members of the political community of the motherland. Several years later, in 1792, exiled Patriots residing in revolutionary France proposed the destruction of the chartered companies and the introduction of a system of colonial representation in a legislative body in the motherland. ${ }^{28}$ National representative Jacob Hahn, chair of the Constitutional Reform Committee, had likewise expressed in a letter to Wiselius and his colleagues his view that the Batavian Republic should drop the concept of colonies altogether; the overseas territories were to be regarded as 'members of the Dutch state'. ${ }^{29}$ The Wiselius report, in short, expressed a line 
of reasoning that had been articulated in various ways in the preceding decade.

The Wiselius report readily expressed its awareness that by proposing the political and constitutional unity of the empire they touched upon a 'highly sensitive issue'. The recent turmoil in both the British and the French empires had left a deep impression. The British, on the one hand, had been unable to prevent rebellious American revolutionaries from founding a union of independent states. The revolutionary French, on the other hand, were unable to prevent a rebellious army of former slaves taking control of large parts of the island of Saint-Domingue.

The Dutch thus faced the predicament of finding a middle course between two undesirable options, the report suggested. Generally, Batavian revolutionaries supported the American declaration of independence as a legitimate political act. In their view British imperial policies towards the American colonists had been arbitrary, they had trodden their rights unlawfully. American rebels were therefore justified in taking up arms for the sake of an anti-imperial revolution. From a metropolitan point of view, the French Revolution represented a different challenge, one that resembled the situation of the Dutch themselves. In contrast to the British-American conflict, the French metropole itself was now engaged in revolution. The question became how the imperial realm should be updated according to the principles of the equal rights of man, popular sovereignty, and representative democracy. Inevitably, the 'disaster' of the French-Caribbean plantation colony Saint-Domingue, became the primary reference point for Dutch revolutionaries (as well as for numerous conservative Orangists).

What has come to be known as the Haitian Revolution was a highly complex series of events. With the outbreak of the French Revolution, Saint-Domingue's French white planters seized the opportunity to demand representation in the metropole but were soon abhorred by any suggestion that revolutionary principles should apply to their slave society. Free Saint-Dominguan people of colour, in contrast, embraced the rhetoric of equality, rights, and citizenship and pushed for reform. The subsequent imperial policies coming from the French metropole were indecisive and highly ambiguous. The stakes were raised when enslaved people of African descent mounted a rebellion on the northern plain of the island in the Summer of 1791. Their uprising threatened to overthrow the entire system of slavery and endangered the exploitation model of the plantation colony. In order to prevent losing control, as 
Spanish and British troops started to invade the island, French commissioners decided to promise formerly enslaved black rebels French citizenship if they would fight on their side. This decision, a mixture of idealism and opportunism, was confirmed by the French National Convention in February 1794.

The details and complexities, often even the basic chronology of events, were lost on most Dutchmen. For example, it was widely asserted that the war and anarchy on the island was caused by the French decision to abolish slavery (in fact, the rebellions of both coloured and black insurgents preceded this decision). The general perception was one of a French revolutionary regime naively applying a set of ideals to a far-off place widely different in terms of climate, soil, social structure, mentality, and mores. As the Wiselius report put it, the application of 'high-minded philosophical principles' without considering the particular circumstances of distant lands was a grave risk. But it was equally dangerous to continuate the 'arbitrariness' of the pre-revolutionary era, thereby betraying the very principles upon which the revolution was based in the first place. The disastrous consequences of both imperial policies- the British and the French-were still 'fresh on everyone's memory'. In light of these imperial experiments, the report inserted the caveat that for the moment the rights and duties that in principle applied to the entire republican empire could justifiably be 'determined, limited, and amended' if the common good required such. ${ }^{30}$ The intended constitutional 'unity and indivisibility' of the Dutch imperial realm, it turns out, was qualified from the very beginning.

After consideration of the Wiselius report, the Constitutional Revision Commission was internally too divided to arrive at a final decision about the constitutional articles concerning the colonies. The National Assembly hence decreed the formation of a new committee in February 1797. Chaired by representative Jacob Hendrik Floh, it finished a report in early April. On Saturday April 22, 1797, they presented the report (hereafter: Floh report), including a draft title for the colonies, to the National Assembly. ${ }^{31}$

\section{The Floh Report}

Although often ignored, the Floh report is arguably the most elaborate theoretical reflection on the nature of colonies produced in the eighteenth-century Dutch Republic. ${ }^{32}$ It did not shy away from asking 
four fundamental questions: what, actually, are colonies? For what purpose should they be protected and maintained? What are the relations between the motherland and her colonies? And finally, how should they be governed? To answer the first question-what are colonies?-the authors of the report took a short historical detour. Their concise history of the Dutch colonial enterprise commenced with the observation that it was not overpopulation (as in the colonies of antiquity) but the 'spirit of commerce' among 'private individuals' that had led to new discoveries and settlements in other parts of the world. The motherland, privileging certain private individuals with patents and charters, pledged to take the 'newly discovered lands under her custody and protection'. This pledge required in turn that all commodities and agricultural produce were destined for the motherland. This reciprocal agreement, this 'contract', as the Floh report put it in typical revolutionary language, was the primary foundation of the establishment and conservation of the colonies. Based on this protection pledge and because the Republic had 'planted her flag' in these lands-'a sign of property' - these new lands could be considered 'possessions of the State'.

The Floh report's language of 'contract' and 'private individuals' is revealing. It deliberately downplayed the collective nature of trading companies as corporate bodies. The revolutionary discourse of individuals who consent to a contract which guarantees their natural and civil rights did not allow for 'intermediary' corporate institutions. Colonies were hence defined as 'those lands the state has taken possession of and has taken under its protection, so as to strengthen its commerce in Europe through the colony's products or trade, and to provide its own market with a greater quantity of goods which can be traded or sold to other peoples, so as to defray the small quantity of products generated on its own European soil'. This was far from an elegant definition, but the message that colonial trade and commerce was a state affair was clear enough. Strengthening commerce, however, was not seen as a goal in itself. Rather, 'the glory and wealth of all contemporary societies of Europe depend merely upon the quantity and extent of their commerce'. The answer to the second question, then, was that the state must protect his overseas colonies in order to pursue glory, retain its status among the leading trading nations, and secure the state's wealth and independence. ${ }^{33}$ The report was silent on the notion of benevolent colonial rule. In fact, the non-Dutch peoples inhabiting the colonial possessions were not mentioned at all. 
Proceeding from this foundation, what are the relations between the motherland and the colony (question three)? Essentially, the Floh report restated the argument that the relationship between metropole and colony is governed by a 'primitive, mutual contract based on consent'. The implications were twofold. On the one hand, 'arbitrary rule' is out of the question. The colonists 'retain their natural and civil rights' (in so far as they had not been renounced in the contract), thus placing limits on the state's authority. The colonists, in their turn, could not unilaterally terminate this contract; that would amount to 'open rebellion'. The report thus warned against the mistakes made by the British, while simultaneously seeking to eliminate any justifiable ground for colonial rebellion.

The Floh commission was careful to point out that since the VOC was formally still in existence (as a nationalized company), the notion of a 'direct' contractual relationship between colonists and the state did not yet apply to the East Indies. There the 'contract' was initially made between colonists and the VOC. Until the expiration of the VOC patent, the Floh report advised, the representatives of the Batavian people could not yet lay down definitive constitutional settlements with the East Indian possessions. Yet the point was clear: the moment the patent expires, the East Indian Company's possessions would immediately become the possessions of 'the Batavian people', and the inhabitants of the East Indian territories would be regarded on the same footing as those of the West.

The answer to the fourth and final question concerned the governance and administration of the colonial possessions. The Floh report maintained that the state ought to be responsible for law and order in the colonies, including the observance of all agreements between motherland and colony. The appointment of civil servants is the responsibility of the state, although the colonists have the right to appoint officials in the legal and police apparatus. Finally, only the state is authorized to levy taxes on agricultural and trade commodities. Although a lot of details and practicalities were still missing, the groundwork for colonial state-building was laid. ${ }^{34}$

Two major differences between the Wiselius report and the Floh report stand out. First, the Floh report explicitly chooses to designate the overseas territories not as 'parts', 'members' or 'departments', but as 'unalienable possessions of the state'. Notwithstanding the consent-based, 
contractual understanding of the relationship between colony and motherland, this designation clearly points to an understanding of the relationship between motherland and colony in terms of subordination. The colonies were not considered on an equal level with, say, provinces. Secondly, unlike Wiselius c.s., the Floh report posited that the metropolitan administration of the colonies must be vested in a governmental body 'separated from any other governing body'. This special governmental body was subjected to the legislative power. The colonial possessions, in this scheme, lack the right of political representation in the Republic's supreme legislative body.

This was an unambiguous statement of political sovereignty over the overseas 'possessions of the state'. Significantly, in the extensive debate following the introduction of the Floh report, this vision of a state-led colonial empire was not disputed. Instead, the debate immediately gravitated around the passionate criticisms regarding the report voiced by the leading republican-democratic representative Pieter Vreede. His main point of critique was that the constitutional articles made no mention of ending the institution of slavery. The Floh report, with reference to Saint-Domingue, had dismissed the 'mistaken and premature' application of 'mesmerizing and conjuring notions of universal freedom and equality of rights'. In the French empire this had led to the 'destruction of all social order'. Vreede, however, urged the Floh committee to go back to the drawing board and reconsider the omission of any reflection on how to end slavery. A majority of representatives in the National Assembly concurred to sending the committee back to work. Several weeks later, the Floh committee presented a new report addressing the issue. Again, Saint-Domingue was the main point of reference. The enslaved colonial population of African descent, it was argued by the committee members as well as numerous representatives, were not 'civilized', not sufficiently enlightened, to assume the rights and duties of free citizens. They were comparable to 'children'. ${ }^{35}$ To prevent the lamentable French-Caribbean scenes of war and anarchy, the constitution should therefore refrain from addressing the slavery question. The political framework underlying this constitutional silence was clear: the colonial empire was not an integrated part of one 'indivisible' constitutional realm as the Wiselius report had argued, but a hierarchically subordinate territory to be ruled by 'special' laws. ${ }^{36}$ The National Assembly accepted the report with a majority of votes. 


\section{The Constitutions of 1798 and 1801}

Although it is hardly ever noticed, it was this outline of the political architecture of the imperial realm by the Floh report that would be essentially maintained in the following constitutions. In August 1797, the National Assembly offered a draft constitution to the enfranchised part of the Dutch citizens in a referendum. But the democraticrepublican camp had waged a passionate campaign against it. Across the political spectrum it was considered an ugly compromise that, in the end, satisfied no-one, and was voted down by a large majority. After a coup d'état of democratic-republican radicals (including Vreede) backed by French troops in January 1798, a new constitution was soon drafted and put to the vote. Although the radical faction of democratic-republican revolutionaries now had a free hand in drafting a new constitution, the Constitution of May 1798 stuck to the definition of the overseas territories as state 'possessions', not as departments (or members). They were now directly subjected to the motherland's executive power and deprived of any voice in the legislative power. The articles on colonies were moreover silent on non-Dutch inhabitants of the colonies, slavery, and the slave trade. A further specification of the constitutional settlement was left to a newly-chosen legislative body.

The radical coup d'état of January 1798 was soon followed by another coup six months later. The role of the democratic-republicans faded out; a new mood of moderation took hold. Three years later, in 1801, a more authoritarian political regime was established. A new constitution, written and forced through under Napoleon Bonaparte's command, vested the highest political authority in a small, centralized executive body, the so-called 'State Authority' (Staatsbewind). The 1801 constitution established two administrative councils, one for the West Indies and one for the East Indies. These Councils were 'directly subordinate' to the Republic's new executive, the State Authority. This was an affirmation of the state's supreme imperial sovereignty as formulated in the preceding revolutionary years.

The new constitution of 1801 stipulated that a new charter was to be drawn for the Asiatic Batavian possessions. The membership of the committee that was assigned to this task was of mixed composition. Dirk van Hogendorp, a fierce critic of the established East Indian ruling elite and a declared admirer of Raynal and Rousseau, was named a member of the charter committee. ${ }^{37}$ But he would soon be toppled 
from his post. S.C. Nederburgh, a member of the very East Indian ruling elite Van Hogendorp had criticized, was thus able to leave his mark on the charter. The final 'Charter for the Foundation of Government and Administration of the East Indian Possessions' of 1804 was preceded by a much longer advisory report containing the underlying views and reasoning behind it (published in late August 1803). Although the Charter only functioned for a few years, historians have assigned it a foundational status. The set of guiding principles for the Dutch imperial empire it put forth, however, did not significantly alter the groundwork that was laid during the Batavian Revolution. The charter confirmed the Floh report's principle that the territories in the East Indies were 'possessions of the state' subjected to the State Authority. The colonial possessions were furthermore to be governed in such a way so as to attain the 'highest stage of prosperity', to arrive at the 'most profitable commerce', and to become 'most beneficial for the land's finances'. The one-way relationship was captured by the claim that the 'colonies exist for the motherland; the motherland not for the colonies'. ${ }^{38}$ The native inhabitants of the Dutch East Indies were there to be exploited as subjects, not to be emancipated into citizens.

The post-Napoleonic, Restoration constitution of 1815, finally, neither entailed a fundamental innovation. It placed the 'colonies and possessions of the state in other parts of the world' under the direct authority of King William I of Orange. Strictly speaking, already in 1806, the French King Louis Napoleon (Napoleon Bonaparte's brother) had assumed this authority as king. But as we have seen, the transformation took place during the Batavian Revolution. It was during this period that the overseas territories were defined as 'possessions of the state' under the sovereign authority of the executive power in place (whether it be an executive council or a king). When King William I of Orange assumed this role of highest political authority over the colonies, he affirmed a conceptual transformation that was essentially already settled by the end of the Batavian Revolution.

\section{The Dutch Imperial Nation-State in Perspective}

What is the significance of this transformation of the company-led Dutch trading empire into a state-led colonial empire? On a conceptual and constitutional level, the corporate sovereignty of trading companies was eliminated. The late eighteenth-century constitutional innovation of the 
Dutch imperial realm can be seen as an effort to dismantle 'corporate sovereignty' and establish a clearer separation of colonial governance on the one hand and trade on the other hand. The latter-the effort to separate trade from politics-was never carried through. With the establishment of the Dutch Trading Society (Nederlandse Handelsmaatschappij) by King William I in 1824, a new state-backed and largely state-owned enterprise, the Dutch state strengthened its supervision of overseas trade.

From a comparative perspective, it is also instructive to observe that the nationalization and liquidation of the VOC (and the WIC, for that matter) was more abrupt than the gradual takeover of the East India Company by the British state. After the Battle of Plassey against the Nawab of Bengal (1757) and the Seven Years War (1756-1763), the British East India Company had gained vast territorial acquisitions. Lord North's 1773 Regulating Act was a first step in centralizing the administration of India. In 1784, William Pitt's so-called India Act established a Board of Control to monitor and instruct the EIC executives, thus subjecting the EIC to direct state supervision. A series of regulations and acts between the 1790s and 1820s further deprived the EIC of its semi-autonomous status within the British Empire. In the last quarter of the eighteenth century, the EIC thus became, as P.J. Marshall put it, 'a subordinate instrument for carrying out imperial purposes rather than as an autonomous member of the British empire'. ${ }^{39}$ Formally, the question of sovereignty remained unresolved, but it was widely accepted that the EIC managed its territories in name of the British state. The EIC was only formally abolished after the Indian Rebellion of 1857-1858.

Because of its relative weakness, the Dutch States General was not capable of gradually reforming and incorporating the VOC into the state structure in the way the British incorporated the East India Company into the British Empire. Until the Batavian Revolution, the Dutch Republic lacked a strong parliament, a powerful executive, and the unity to force the VOC to submit to a high degree of state supervision. In comparison with the gradual takeover of the East India Company by the British state, the assumption of political sovereignty of the Dutch state over the trading company's possessions was belated, but once it took place, also more abrupt and far-reaching.

A second way to put the constitutional innovation into perspective is to observe that, in the short run, the constitutional innovation of the imperial realm around 1800 had a mixed impact on colonial practices, institutions, and governance cultures. This is perhaps one of the primary 